Ks. Tomasz Kaczmarek

\title{
W miejsce biografii ${ }^{1}$
}

Zwyczajowo księgi jubileuszowe otwiera szkic biograficzny o ich protagonistach. Tym razem jest on pomyślany w kategorii pogodnego spojrzenia samego autora na niektóre odsłony z jego życia. Będzie tu chodziło o spojrzenie razem z Czytelnikiem na okruchy dobra, jakie stały się udziałem nie tylko jego.

\section{Początki}

Dzień urodzin przypadł na 6 stycznia 1950 roku, kiedy w liturgii Kościoła katolickiego obchodzona jest uroczystość Objawienia Pańskiego. Parafią pochodzenia było Chełmno, miejscowość przywołująca smutne wspomnienia z czasu II wojny. Z dworu, z którego wyruszały do pobliskiego Lasu Rzuchowskiego samochody-komory gazowe załadowane skazańcami na zagładę, pozostawały w latach pięćdziesiątych tylko ruiny. Na jaśniejszych ścianach piwnic były jeszcze wtedy widoczne plamy krwi ofiar: Żydów i Polaków.

Zupełnie innego rodzaju wydarzeniem z dzieciństwa, które najmocniej wpisało się do pamięci, było bardzo głębokie przeżycie wieczorem 25 sierpnia 1959 roku na Jasnej Górze, przed ołtarzem Krzyża Świętego w bocznej nawie Kaplicy Cudownego Wizerunku, kiedy zapadła nie-

1 Niniejszy materiał jest szkicem autobiograficznym do księgi jubileuszowej, dedykowanej autorowi z okazji 25-lecia prac przy Kongregacji Spraw Kanonizacyjnych. Księga została wydana jako 12 tom „Studiów Włocławskich” (2009). Zarząd Teologicznego Towarzystwa Naukowego WSD Włocławek, jako Wydawca tegoż czasopisma, wyraża zgodę na przedruk w „Vox Patrum” tegoż tekstu. 
odwołalna decyzja: „Będę księdzem”. Była to tak bardzo osobista sprawa, że nie odsłaniałem jej nikomu aż do czasu, gdy w ręku miałem świadectwo maturalne, choć i tak wielu się tego już wcześniej domyślało.

\section{Czas seminarium}

Od momentu zgłoszenia się do seminarium we Włocławku z niecierpliwością wyglądałem dnia rozpoczęcia zajęć. W wyznaczonym terminie na zjazd alumnów, 14 września 1968 roku, pojawiłem się na furcie w seminarium możliwie jak najwcześniej. I tu od razu czekało mnie odkrycie. Przyjął mnie ksiądz wicerektor, którym był wtedy nieżyjący już dziś biskup Roman Andrzejewski. Z ujmującą dobrocią, która przerastała moje oczekiwania, poprowadził do swojego skromnie umeblowanego mieszkania „przy zegarze”, by tam przekazać kilka nieodzownych informacji. To wszystko było otoczone takim taktem pełnym serca, że byłem wprost zdumiony. Półgłosem wyrwały mi się wtedy słowa: „Mój Boże, ksiądz a taki dobry człowiek!".

Okazuje się, że odkrycia przychodziły raz po raz, a dotyczyły przeróżnych realiów seminaryjnego życia, regulaminu, zwyczajów i ludzi. Zatrzymam się tylko przy naszych księżach profesorach, na których zawsze patrzyłem z dużym szacunkiem. Każdy z nich był bardzo inny i miał w moich oczach coś godnego uznania. Nie zmienił tego i pewnego rodzaju zimny prysznic, jakim stał się egzamin z historii filozofii na zakończenie pierwszego roku, na który, idąc za zachętą wykładowcy, zgłosiłem się dwa dni przed czasem. Kiedy recytowałem z pamięci osławiony wówczas skrypt, słyszałem słowa aprobaty połączone z gestami, których nie da się zapomnieć: „A, to inteligentny studencik”. Gdy jednak tenże „studencik” wpadł na pomysł, żeby zacząć dysputować wokół wyuczonego materiału, od razu usłyszał, że z tą inteligencją jest zupełnie inaczej. Nie pozostało nic innego, jak podjąć ciąg dalszy recytacji. Wtedy znów był ,inteligentny studencik”. Niesmak, jaki pozostał z owego egzaminu z filozofii ,przed czasem”, rozpłynął się później przy innych profeso- 
rach, jak przy ks. prof. Stanisławie Mazierskim czy ks. prof. Stanisławie Kowalczyku.

Przytoczę jeszcze jeden egzaminowy epizod. Na roku IV prowadził egzamin z teologii moralnej ks. prof. Stanisław Olejnik. Miał zwyczaj, że prosił na salę po dwie osoby: jedna odpowiadała, a druga w międzyczasie przygotowywała się. Akurat kolega, który zdawał razem ze mną, nie był tego dnia w najlepszej formie. W trakcie odpowiadania popełnił tak niefrasobliwy błąd, że mnie poruszyło, ale nie miałem możliwości mu pomóc. Gdy ksiądz profesor mu przerwał i jeszcze raz podszedł do tematu od innej strony i znów się powtórzyło to samo, byłem zaskoczony reakcją. Normalnie można było spodziewać się surowej reprymendy, a tu nic z tego. Ks. prof. Olejnik popatrzył na niego przez chwilę z jakimś autentycznym smutkiem na twarzy, a potem ściszonym głosem powoli powiedział: „Egzamin zakończony. Proszę już wyjść”. Więc wyszedł, a ja nabrałem do profesora jeszcze większego szacunku.

Wyczekiwany od tylu lat dzień święceń kapłańskich, 15 czerwca 1974 roku, nadszedł niespodziewanie szybko.

\section{„Teraz pojedziesz uczyć się do Rzymu”}

Po trzech latach, jakie błyskawicznie przeminęły na dwóch wikariatach w latach 1974-1977, najpierw w Choczu nad Prosną a potem w Izbicy Kujawskiej, usłyszałem z ust księdza biskupa ordynariusza Jana Zaręby „Teraz pojedziesz uczyć się do Rzymu”. Miałem udać się na pięcioletnie specjalistyczne studia do Instytutu Patrystycznego „Augustinianum” przy Uniwersytecie Laterańskim. Po miesiącach udręk, żeby otrzymać paszport a także włoską wizę pobytową, wreszcie we wrześniu 1977 roku było już wiadome, że mogę wyruszyć w kompletnie dla mnie nowy świat, a emocje powiększało jeszcze to, że jechałem bez fachowego przygotowania do przedmiotu, bez znajomości języków, a na dodatek i bez pieniędzy na studia. 
Zanim wsiadłem na Dworcu Gdańskim w Warszawie do pociągu w kierunku Italii, było oczywiście jeszcze spotkanie z księdzem biskupem Janem Zarębą. Kiedy go zapytałem, co będzie z opłatą za studia, popatrzył na mnie a potem poklepał mnie kordialnie po ramieniu i powiedział: „Bracie, bracie, pobłogosławię ci, to sobie poradzisz!”. Po czym, po krótkiej modlitwie, udzielił błogosławieństwa. Ja przyjąłem słowa biskupa bardzo na serio i tak samo na serio westchnąłem do Pana Jezusa: „Panie Jezu, skoro tak mówi Twój biskup, to wiem, że Ty za niego nadrobisz, co potrzeba". Mogę zaświadczyć, że od chwili wyruszenia pociągiem do Rzymu w dniu 20 września tegoż roku towarzyszyła mi nieprzerwanie odczuwana opieka z nieba. Nie znaczy to, że od tej pory moje życie nad Tybrem płynęło sielsko i anielsko. Było po prostu typowo dla Bożej pedagogii: Pan Bóg umacniał, udzielał pomocy bezpośrednio albo poprzez Jego ludzi, dokonywał cudów, gdy było to potrzebne, ale jednocześnie prowadził drogą zakosztowania krzyża wprost „do szpiku kości”, by nauczyć trochę mądrzejszego patrzenia na wszystko.

Rzym pozostaje niezwykłym miejscem, gdzie można było się wiele nauczyć. Tu dopełniało się moje przekonanie, że studium dziedzin teologicznych jest wyrazem miłości Kościoła. Właśnie z takiego czasu pochłaniania na wszelki możliwy sposób wiedzy z dziedziny Ojców Kościoła, a także z innych sektorów, gdy raz po raz zapisywałem się na wybrane wykłady na innych uczelniach rzymskich, jak w Instytucie Archeologii Chrześcijańskiej czy „Biblicum”, wracają wspomnienia spotkań z wyjątkowymi postaciami, chrześcijanami wielkiego pokroju. Do takich należał o. prof. Agostino Trapè OSA, niegdyś przez dwie kadencje przełożony generalny Zakonu Świętego Augustyna, ekspert Soboru Watykańskiego II, światowej sławy znawca św. Augustyna, jakby uosobienie dobroci i radości, który potrafił porywać dla tegoż Ojca Kościoła swoich słuchaczy. Był w takim gronie i o. prof. Jean Gribomont OSB, rozmiłowany w nauczaniu św. Hieronima, organizator prac nad wydaniem Neowulgaty. 
Któregoś razu, gdy poszliśmy go odwiedzić w jego opactwie, zastaliśmy tego cenionego na świecie naukowca przy pucowaniu toalet klasztornych (!). W habicie podciągniętym dość wysoko na pasie, by go nie zmoczyć przy schylaniu, odezwał się do nas z rozbrajającym uśmiechem: „Jeżeli możecie, poczekajcie jeszcze kilka minut, zaraz skończę. Dziś jest tu moja kolejka". Przy takich ludziach o zdumiewającej głębi wiedzy, którzy jednocześnie - jeden i drugi - zakończyli życie w opinii świętości, chrześcijaństwo i teologia nabierały imponujących barw.

Ale Rzym, to przede wszystkim szczególne miejsce dla chrześcijaństwa, gdzie przy grobach Apostołów żyje „pamięć” Kościoła i żywo pulsuje jego powszechność, gdzie spotykają się uczniowie Chrystusa wszystkich ras, kolorów skóry, dzieląc tę samą wiarę mimo kompletnie odmiennych mentalności i kultur. W mieście Apostołów, tysięcy świętych na przestrzeni dwudziestu stuleci - najbardziej tworzących historię Kościoła - w mieście nakładających się epok kultury historia przepowiadania Ewangelii nabierała po prostu innego wymiaru.

Jakimż przeżyciem była możliwość spotykania z bliska papieża Pawła VI, Jana Pawła I, a potem niezwykły pontyfikat naszego papieża. W rzeczywistości sama tylko opowieść o studenckich czasach rzymskich wystarczyłaby na bardzo barwną księgę.

\section{We Włoclawku}

Od września 1983 roku już pakowałem moją bibliotekę patrystyczną, by stopniowo przez kilka miesięcy przesłać jej zasadniczą część do Polski autobusami pielgrzymów, którzy mimo niebywałych trudności, z fantazją i entuzjazmem tłumnie przyjeżdżali na spotkania z Ojcem Świętym. Miałem wielką nadzieję na niezwłoczne wykorzystywanie jej w Polsce. Biskup ordynariusz miał jednak inną wizję. Po prostu polecił mi przyjechać w styczniu 1984 roku bezpośrednio z lotniska do domu biskupów włocławskich, by tam zamieszkać i przejąć od zaraz funkcję swojego kapelana, notariusza kurii, zajęcia w seminarium i to, co na bieżąco nio- 
sło życie w otoczeniu biskupa. A niosło niemało. Przecież wizytówką tamtych czasów była śmierć ks. Jerzego Popiełuszki.

Jeszcze wiosną 1984 roku bp Zaręba, któremu zależało na ożywieniu prowadzonego procesu beatyfikacyjnego Sługi Bożego bp. Michała Kozala, polecił mi, by się tym zająć pod kierunkiem relatora Kongregacji, o. Michała Machejka OCD. Jesienią tegoż roku włączono mnie do grupy zaprzysiężonych cooperatores externi (współpracownicy zewnętrzni) Kongregacji. Tak oto 35 lat temu zaczęła się wielka przygoda ze świętością kanonizowaną: w przyspieszonym rytmie należało się teraz nauczyć podstaw prawa kanonizacyjnego, a jednocześnie przystępować bezpośrednio do pracy.

Ks. bp Jan Zaręba nie doczekał się jednak beatyfikacji. Odszedł do Pana wczesnym rankiem 22 listopada 1986 roku, w sobotę przed niedzielą Chrystusa Króla. Wieczorem w przeddzień, gdy wróciłem do domu później na kolację, po zakończeniu sesji Teologicznego Towarzystwa Naukowego w Seminarium, przyszedł jeszcze do mnie porozmawiać, a kilka godzin później pochylałem się już nad stygnącym ciałem biskupa moich święceń, zdanego teraz tylko na łaskę innych. Kilka dni później złożono go w krypcie bazyliki katedralnej, gdzie przy wejściu widnieje wymowny napis: Olim antistites, nunc ossa et cineres.

Gdy diecezję włocławską objął w grudniu 1987 roku nowy biskup, Henryk Muszyński, znów odżyła kapelania, ale w nieco innym stylu. Według umowy miała trwać tylko trzy miesiące, na czas wprowadzenia nowego biskupa w diecezję, a faktycznie przedłużyła się do półtora roku. W lipcu 1989 roku przeprowadziłem się do seminarium.

\section{Studium Teologii}

Przy Seminarium Włocławskim funkcjonował Instytut Wyższej Kultury Religijnej (IWKR) dla świeckich, który swoimi korzeniami sięgał jeszcze 1938 roku. Od sierpnia 1989 roku przypadło mi podjąć jego prowadzenie. Było wprost radością prowadzenie zajęć dla dwudziestu 
kilku osobowej grupy słuchaczy, którzy mieli już pokończone inne studia, zdobyli różne zawody, a teraz sięgali do teologii dla pogłębienia swego życia wiary. Sytuacja jednak szybko zmieniła się już po roku.

W następstwie przemian ustroju politycznego, jakie zostały podjęte w Polsce po 1989 roku, w 1990 do programów szkolnych powróciło w pełnym wymiarze nauczanie religii. Brakowało jednak przygotowanych katechetów. Okazało się, że działający w tym czasie IWKR o trzyletnim cyklu zajęć był faktycznie jedynym ośrodkiem w diecezji, który zajmował się względnie systematyczną formacją teologiczną laikatu, nie dając jednak specyficznej, w szerokim wymiarze, formacji pedagogicznej i katechetycznej. Mimo to przyjęta była w diecezji włocławskiej praktyka, że jego absolwenci mieli tytuł do ubiegania się o misję kanoniczną do nauczania religii w zakresie szkoły podstawowej lub pracy w duszpasterskich punktach poradnictwa rodzinnego. Trudno przeto było się dziwić, że osoby, którym w 1990 roku powierzono nauczanie religii choć w większości były jeszcze do tego nieprzygotowane merytorycznie - zaczęły kierować się do naszego Instytutu. Swoistą sytuację przyniósł dzień 13 października 1990 roku, kiedy w trakcie prowadzenia zajęć w ramach programu czwartego semestru IWKR-u niespodziewanie na salę wkroczyła ponad 60-osobowa grupa nowo zaangażowanych w szkołach nauczycieli religii wprost z żądaniem przyjęcia ich w nadzwyczajnym trybie na zajęcia. Przyszli bezpośrednio ze spotkania zorganizowanego dla nich przez Wydział Katechetyczny Kurii. W sumie na zajęcia w roku 1990/1991 zapisało się 120 osób, co stawiało nas wobec zupełnie nowych zadań, choćby i od strony rozwiązania problemów lokalowych.

Ale były też i niepokojące pytania o ideowość masowo przyjmowanych katechetów, a teraz naszych studentów. Tytułem przykładu niech będzie tu wolno przytoczyć przypadek, kiedy pośród osób składających papiery o przyjęcie znalazł się i funkcjonariusz UB, który utrwalił się w mojej pamięci trzynaście lat wcześniej z bardzo upokarzających rozmów w przeciągu kilku miesięcy w urzędzie paszportowym, przed otrzy- 
maniem paszportu na studia zagraniczne. Po rozpoznaniu już nigdy się nie pokazał.

Po trzech pierwszych semestrach zajęć z tą właśnie wielką falą kandydatów na katechetów w dzienniku zajęć na IWKR, pod datą 25 stycznia 1992 roku, zamieściłem adnotację o następującej treści: „Ideowość, zainteresowanie sprawą Kościoła - niskie. Frekwencja na zajęciach średnio nie przekraczała $60 \%$. W ostatnim dniu zajęć, kiedy ostatnie dwie godziny wykładowe poświęcone były na program formacji duchowej i uroczyste zakończenie I-go roku pracy, wzięło udział tyko 48 osób”.

Dla mnie było oczywiste, że przygotowanie katechetów, nauczycieli wiary, stanowiło wprost palące wyzwanie. Nowa sytuacja $\mathrm{w}$ realiach diecezji domagała się jak najpilniejszego przekształcenia IWKR-u w instytut o charakterze w pełni formacyjnym i pełnoprawnym akademickim, dającym także możliwość uzyskania stopnia magisterskiego przez absolwentów katechetów. Trzeba powiedzieć, że sprzyjającą okolicznością ku temu było przyjście do diecezji od 1992 roku nowego biskupa, Bronisława Dembowskiego, który wtedy jeszcze pełnił funkcję dziekana Papieskiego Wydziału Teologicznego (Sekcja Św. Jana Chrzciciela) w Warszawie. Zaraz po nim tę funkcję przejął ks. prof. Ludwik Królik, który w tym czasie był moim wicepostulatorem dla męczenników z archidiecezji warszawskiej. To wszystko w sumie bardzo sprzyjało utworzeniu Studium Teologii jako zamiejscowego instytutu przy PWTW. Teraz trzeba było niezwłocznie przebudować profil zajęć, poszerzyć kadrę wykładowców i znaleźć miejsce a także fundusze na prowadzenie dzieła. Tego nie można było absolutnie odkładać na korzystniejszy czas.

Wypracowanie szczegółowego programu organizacji zajęć pełnego, sześcioletniego cyklu, aprobata Wydziału Teologicznego, a następnie zatwierdzenie ze strony Kongregacji Studiów i Seminariów oraz aprobata Ministerstwa Edukacji i Szkolnictwa Wyższego, wszystko to udało się przeprowadzić w przeciągu siedmiu miesięcy, co należałoby oceniać 
w kategorii spraw bardzo nietypowych. Studium Teologii funkcjonowało już od pierwszego semestru roku akademickiego 1992/1993.

Nikt się nie łudził, że dzieło osiągnęło doskonałą postać. Ta młoda instytucja pozostawała jeszcze w fazie rozwijania się i ciągłego tworzenia, zmierzając się na bieżąco z problemami i trudnościami przeróżnej natury. Na dodatek lata 1993 i 1994 zaznaczyły się we Włocławku tym, że wobec instytucji i obiektów kościelnych nasiliły się akty wandalizmu ze strony tzw. „nieznanych sprawców”, wobec których organa bezpieczeństwa miasta zupełnie nie okazywały zainteresowania, by ich wykryć. Tego również doświadczało Studium: jedynie w październiku 1993 roku trzykrotnie porozbijano nam duże szyby okienne w salach wykładowych w domu na Gdańskiej 6.

Dwa pierwsze lata funkcjonowania Studium dawały tytuł do pewnego rodzaju poczucia satysfakcji z dokonania słusznego początku, jak i pozwalały żywić uzasadnione przekonanie, że dzieło już nie załamie się i będzie rozwijać się pod kierunkiem nowej dyrekcji, co nastąpiło, kiedy jesienią 1994 roku musiałem się przenieść na trzy lata do Rzymu, do prac nad męczennikami przy Kongregacji. Tych dwóch dzieł dalej już nie dało się prowadzić na odpowiedzialny sposób jednocześnie.

Najlepszą wizytówką Studium Teologii są jego absolwenci, cenieni w szkołach jako nauczyciele i wychowawcy. Do roku 2019 nieco ponad 1000 absolwentów uzyskało stopień magistra ze specjalnością katechetyczną czy poradnictwa rodzinnego. Ci ludzie włączyli się ofiarnie w życie tak diecezji włocławskiej, jak i sąsiednich. Trud nie był daremny.

\section{Męczennicy przywołani przez bł. Michała Kozala}

Choć ta sprawa ma największy ciężar, dotykam jej tylko w dużym skrócie, ograniczając się jedynie do kilku uwag. Bł. Michał Kozal w dekrecie beatyfikacyjnym otrzymał zaszczytny tytuł „Mistrza Męczenników”. Czas pokazał, że faktycznie on również przywołał do beatyfikacji duże 
grono tych, którym przewodził w składaniu świadectwa. Tak rozpoczął się proces beatyfikacyjny męczenników, jaki w Polsce nie miał precedensu. Tym razem zorganizowanie prac i rozpracowanie metody studium o męczeństwie pozostawało w moich rękach. O zakresie prac mogą już coś powiedzieć same liczby. Po długich konsultacjach z diecezjami i zgromadzeniami zakonnymi w sumie przedmiotem uwagi było ponad trzysta osób, które poniosły śmierć z rąk hitlerowskiego prześladowcy. Z nich tylko 108 zostało przedstawionych na końcu do beatyfikacji. W trakcie prac procesowych przyjęto zeznania zaprzysiężone 779 świadków, 221 zeznań „biegłych” historyków i archiwistów, członków komisji historycznych. Pośród materiałów dowodowych rozpatrzono 695 dokumentów dotyczących samego męczeństwa, nie wspominając już o tysiącach innych dokumentów pobocznych dla sprawy. Bezpośrednio w pracach nad dziełem było zaangażowanych ponad 600 osób z całej Polski, jak i zagranicy. Te wszystkie prace udało się przeprowadzić w Polsce zaledwie w przeciągu dwóch lat, a ich owocem były 94 tomy usystematyzowanych materiałów w tzw. Copia publica jako baza do dalszego studium w Kongregacji nad męczeństwem naszych rodaków.

Tam, gdzie podejmowane są dzieła dla chwały Bożej, tam zawsze zaznacza swoją obecność ten, którego Boże słowo określa jako „zabójcę od początku” i „ojca kłamstwa” (J 8,44). W tym dziele też pojawiały się raz po raz niewytłumaczalne przeszkody, eksplozje zła, przeciwności, dziwne zaciemnienia, nieporozumienia. Nie miejsce i nie czas, żeby te sprawy ujawniać w detalach. Z radością natomiast mogę dziś powiedzieć, chociaż też bardzo oględnie, o czymś zupełnie przeciwnym: w dniu rozpoczęcia procesu na uroczystej sesji publicznej w bazylice katedralnej, 26 stycznia 1992 roku - była to 49. rocznica śmierci bł. Michała Kozala po zakończonych ceremoniach sam błogosławiony biskup bezpośrednio potwierdził, że rozpoczyna się bardzo ważne dzieło dla chwały Bożej. A z taką pewnością i Bożym błogosławieństwem inaczej podejmuje się nawet najbardziej trudne wyzwania. 
Od 2003 roku doszedł mi na prośbę księdza prymasa Józefa Glempa jeszcze jeden męczennik - Sługa Boży ks. Jerzy Popiełuszko, tym razem męczennik ateistycznego systemu komunistycznego. Doświadczenia poprzedniego procesu bardzo się teraz przydały przy pracy nad Positio super martyrio w nowych realiach Kongregacji.

\section{Na co podzielić podarowany czas?}

Niejednokrotnie ze strony różnych środowisk słyszałem pouczenia: „Powinieneś się zająć więcej nauką, a nie tracić czasu na inne sprawy”. Czyżby? Przecież te ,inne sprawy” - a wspomnę tylko o dwóch - w różnych sektorach życia Kościoła nie tylko nie blokują autentycznych poszukiwań teologicznych, ale tworzą bardzo przydatne ramy dla nich i do tego, co jest bardzo potrzebne dla budowania chrześcijańskiej cywilizacji miłości. Dlatego nigdy nie było mi żal ani sił, ani czasu, ani środków materialnych, kiedy od 1989 roku w czasie wakacji albo przerw świątecznych, bez rozgłosu, wyruszałem na wyprawy misyjne na wschód. Ich sens niech opowiedzą przynajmniej dwa fakty.

To było w sierpniu 1989 roku, 30 lat temu. Wtedy jeszcze wszechwładnie panował Związek Sowiecki, a wszelkie przejawy religijności były nie tylko surowo zakazane, ale i bardzo dotkliwie karane, zwłaszcza wobec młodszych osób. W ukryciu przed agentami wszechobecnej milicji politycznej KGB z dwoma miejscowymi osobami pojechałem jednego dnia przez knieje i pustkowia do bardzo odległej wioski w rejonie witebskim. W największej chacie czekało już wielu ludzi. Po sakramencie pokuty, sakramencie chorych i po Mszy Świętej trudno się było rozstać. Byłem zdumiony, gdy odkryłem, że jest tam cała grupa ludzi powyżej 90 lat. Jak dali radę tu przeżyć? Jedna $\mathrm{z}$ takich staruszek $\mathrm{z}$ wielkim wzruszeniem powiedziała mi łamiącym się głosem: „Ojcze, jacy my dziś szczęśliwi! Dziś Pan Bóg spełnił nasze modlitwy! Tyle lat się modliliśmy, żeby dał nam jeszcze przed śmiercią spotkać kapłana, by pojednać się z Bogiem. Teraz już możemy spokojnie umierać. Nic nam już więcej nie potrzeba...”. 
Kiedy po trzech tygodniach wracałem z powrotem do Polski, przyszła na pożegnanie duża gromada ludzi. Spoglądali na mnie w milczeniu, w oczach mieli łzy. Wreszcie dyrektorka kołchozu, Rosjanka, podeszła bliżej i na kolanach zaczęła prosić przejętym głosem, po rosyjsku: „Przyślijcie nam kapłanów, bo my tu żyjemy nie jak ludzie, ale jak świnie!”. Dosłownie użyła takich słów. Ci bardzo udręczeni ludzie dobrze rozumieli, jak straszna następuje degradacja człowieczeństwa i kultury, kiedy usunie się z życia Dekalog, gdy nie będzie dostępu do łaski odnawiającej człowieka, gdy braknie mocy miłości strzegącej przed nienawiścią i pychą.

Tak samo nie żal mi było poświęcenia wiele czasu w latach 19901994, kiedy pomagałem w przeniesieniu na polski grunt dzieła prowadzonego przez włoskie zgromadzenie zakonne Sług Miłości nazywanego od założyciela „guanellianami” (św. Luigi Guanella). Gdy miałem okazję poznać bliżej charyzmat tej wspólnoty, uderzał mnie ich sposób patrzenia na dotkniętych upośledzeniem fizycznym i psychicznym, włącznie z najcięższymi stanami. Oni szli z miłością ku tym, którymi inni się brzydzili. Nazywają ich buoni figli, tj. 'dobre, kochane dzieci', dlatego że są kochane przez Boga oraz przeznaczone tak samo do pełni życia i piękna po zmartwychwstaniu. Chociaż przełożonym zgromadzenia brakło w pewnej chwili odwagi do otworzenia we WłocławkuMichelinie pierwszego domu zgromadzenia w Polsce, to jednak dzieło nieco później i tak ruszyło w Skawinie k. Krakowa. W latach dziewięćdziesiątych bowiem przełożeni tegoż zgromadzenia wyhamowali decyzje odnośnie do domu we Włocławku przede wszystkim pod wpływem bieżących, bardzo gorzkich doświadczeń z Nigerii, gdzie tamtejszy rząd bezlitośnie wykorzystał ich inwestycje, wielki nakład finansowy a potem upaństwowił wszystkie ośrodki duszpasterskie, szkolne i charytatywne. Dzieło trzeba było zamykać. 


\section{Epilog}

Ta część wspomnień jest epilogiem tylko w sensie zakończenia tekstu a nie dzieła. Jesteśmy przecież „w drodze” aż do ostatniego dnia życia na ziemi. Spoglądając wstecz na dobre dzieła, jakich Pan pozwolił dokonać, chyba najwłaściwszym będzie otwierać wciąż na nowo Księgę Psalmów na wersecie „Nie nam, Panie, nie nam, ale imieniu Twojemu daj chwałę" (Ps 115,1). 